УДК: 37.036 .5

DOI: $10.32340 / 2514-772 X-2021-1-29-34$

А. А. Давыдова

Кемеровский государственный институт культуры (Кемерово, Россия) davidova_nastya@mail.ru

Научный руководитель - А. И. Юдина, доктор педагогических наук, профессор Кемеровский государственный институт культуры (Кемерово, Россия) yudinaannaivanovna@mail.ru

\title{
РАЗВИТИЕ ХОРЕОГРАФИЧЕСКОГО ИСКУССТВА В КУЗБАССЕ: КЛАСТЕРНЫЙ ПОДХОД
}

\begin{abstract}
Аннотация. В статье анализируется опыт ученых, исследующих роль кластерного подхода в развитии регионов (на примере региона Кузбасс). Изучается опыт создания Сибирского культурного кластера и его влияние на развитие профессионального хореографического искусства в Кузбассе. Рассматривается значительный культурный и творческий потенциал взаимодействия Сибирского культурного кластера и Кемеровского государственного института культуры как важных составляющих развития профессионального хореографического искусства. Делаются прогнозы о дальнейшем развитии хореографического искусства в регионе.
\end{abstract}

Ключевые слова: кластерный подход, культурный кластер, регион, Кузбасс, хореографическое искусство, хореография, балет.

В современной социально-экономической ситуации особую значимость приобретает сохранение культурной идентичности и традиций народов, населяющих Российскую Федерацию. Данное направление обозначено как приоритетное в Основах законодательства Российской Федерации о культуре.

Это отражено и в Государственной культурной политике Российской Федерации, согласно которой приоритетным направлением является развитие русской и национальных культур народов России, создание условий для профессиональной и непрофессиональной творческой деятельности граждан, а также сохранение, создание и развитие необходимой для этого инфраструктуры $[1$, п. 6].

На наш взгляд, развитие хореографического искусства как одно из важных направлений национальной культуры, обладает значимым педагогическим и социально-культурным потенциалом в воспитании молодежи, сохранении культурных традиций и нематериального историко-культурного наследия народов России. Задачей нашего исследования является анализ развития профессионального хореографического искусства в Кузбассе. Данный аспект является актуальным в связи со строительством в регионе Сибирского кластера искусств.

Анализ литературы по теме исследования показал, что многие ученые в своих исследованиях затрагивают тему кластерного подхода в различных направлениях развития страны. По определению М. Портера, кластер - это группа соседствующих взаимосвязанных компаний и связанных с ними организаций, взаимодополняющих друг друга и действующих в определенной сфере, а также характеризующихся общностью деятельности [2, с. 258]. Ученые О. В. Буреш и А. В. Фролов рассматривают кластерный подход как наиболее эффективный инструмент развития региональной политики [3, c. 60].

Об этом свидетельствуют также основные направления современной культурной политики, обозначенные Министерством культуры Российской Федерации, которые направлены на развитие региональной культурной инфраструктуры. Как отметил В. Мединский в рамках «правительственного часа» в Совете Федерации 21 марта 2018 года: «За последние годы был сделан кардинальный разворот в сторону регионов» [4].

Е. В. Паничкина рассматривала кластерный подход с точки зрения культурной региональной политики. Опираясь на её мнение, мы можем описать кластерный подход как неотъемлемую часть стратегического развития регионов, следствием чего является создание и продвижение бренда регионов и повышение их конкурентоспособности [5, с. 104-105].

Учёные Л. И. Кулакова и Н. О. Андросова в своих исследованиях рассматривали кластерный подход в своих регионах проживания: Камчатском крае и Белгородской области соответ- 
ственно [6, с. 128-130; 7, с. 178-180]. Мы же в своем исследовании опираемся на данные по Кемеровской области - Кузбассу как региону, развивающемуся в рамках государственной культурной политики и обладающему значительным культурным и творческим потенциалом.

По данным на 1 января 2017 года обширная сеть региональных учреждений культуры состоит из 407 юридических лиц, в том числе 24 областных учреждений: 318 бюджетных, 38 казенных, 51 автономное. Они различаются по видам деятельности и насчитывают 1901 сетевую единицу.

В Кемеровской области работает:

- 7 профессиональных театров;

- Кемеровская государственная областная филармония, на базе которой располагается множество творческих коллективов, в том числе Губернаторский театр танца «Сибирский калейдоскоп»;

- 637 библиотек;

- 640 клубов различной направленности;

- 43 музея;

- 109 киноучреждений;

- 76 парков культуры и отдыха различных форм собственности;

- Губернаторский культурный центр «Юные дарования Кузбасса»;

- 7 творческих союзов, участниками которых являются более 400 актеров, музыкантов, хореографов, профессиональных художников, дизайнеров, композиторов и литераторов.

Кемеровская область имеет одну из лучших в стране и Сибирском федеральном округе многоуровневую систему подготовки профессиональных кадров. Сеть образовательных учреждений культуры состоит из 109 детских музыкальных, художественных школ и школ искусств, 5 средних специальных образовательных учреждений, а также Кемеровского государственного института культуры [8].

Рассмотрим педагогический и социальнокультурный потенциал предполагаемого взаимодействия Кемеровского государственного института культуры и строящегося в Кузбассе Сибирского кластера искусств для развития хореографического искусства в регионе.

Для реализации задачи по созданию культурных кластеров в различных регионах страны, которая была поставлена в послании Федеральному собранию и отражена в указе Президента Российской Федерации от 7 мая 2018 г. № 204 «О национальных целях и стратегических зада- чах развития Российской Федерации на период до 2024 года» - созданы масштабные проекты строительства культурно-образовательных и музейных комплексов, которые должны в ближайшие годы появиться в таких городах, как Севастополь, Калининград, Владивосток и Кемерово.

В Кузбассе окончание строительства Сибирского кластера искусств планируется в 2023 году. Он будет иметь особое значение в экономическом и социальном плане как для региона, так и в целом для всей Сибири.

Впервые идею создания культурного кластера в Кузбассе озвучил губернатор Кемеровской области Сергей Цивилёв. Он выступил с этой идеей на презентации «Стратегии развития Кемеровской области до 2035 года», где высказался о создании культурного кластера, который объединит все учреждения культуры региона и расширит комплекс услуг в сфере культуры и искусства [8].

Основными целями создания Сибирского культурного кластера являются повышение культурной привлекательности региона и включение его в федеральные культурные проекты, а также создание возможностей для профессиональной реализации молодых специалистов в области культуры.

Многофункциональность кластера искусств будет способствовать созданию условий для повышения общего культурного уровня жителей Кузбасса и Сибири в целом, а также обеспечит для всех категорий граждан обширный доступ к лучшим образцам мировой и отечественной культуры.

Задачами создания Сибирского кластера искусств являются:

1. Повышение доступности и качества образования в сфере культуры и искусства.

2. Обеспечение учреждений культуры Кузбасса высококвалифицированными специалистами.

3. Формирование тройной системы, заключающейся в выявлении, поддержке и развитии талантов на территории региона.

4. Создание условий для обучения профессиональному искусству талантливых специалистов.

Все задачи соотносятся с задачами государственной культурной политики, что ещё раз подтверждает актуальность строительства Сибирского кластера искусств на территории Кузбасса.

В состав Сибирского кластера искусств войдут следующие культурные учреждения: 
- театр оперы и балета (филиал Государственного академического Мариинского театра);

- музейно-выставочный центр (филиал Государственного Русского музея);

- Сибирский кампус Российского государственного института сценических искусств);

- филиал Московской государственной академии хореографии;

- филиал Центральной музыкальной школы при Московской государственной консерватории имени П. И. Чайковского «Сибирский».

В рамках заявленной темы будут рассмотрены реализующиеся в регионе проекты по созданию филиала Московской государственной академии хореографии (г. Москва) и филиала Государственного академического Мариинского театра (г. Санкт-Петербург), которые имеют самое непосредственное отношение к развитию профессионального хореографического искусства в регионе.

Будущий Сибирский филиал Мариинского театра станет прекрасной возможностью приобщения к лучшим образцам вокального и хореографического искусства для жителей региона и прилегающих территорий. На сцене театра планируются выступления солистов Государственного академического Мариинского театра (г. Санкт-Петербург) и Приморской сцены Мариинского театра (г. Владивосток).

На сцене Сибирского филиала Мариинского театра планируется проведение концертных программ для детей и взрослых, в том числе спектаклей и симфонических концертов. Предполагается, что артисты, музыканты филиала Мариинского театра будут принимать участие в гастрольных турах по городам Сибирского федерального округа, чтобы жители региона могли получить доступ к новым культурным возможностям.

Для актёров кемеровских театров и студентов профильных учебных заведений планируются организованные мероприятия в виде разнообразных тематических лекций и мастерклассов от ведущих солистов труппы Мариинского театра. Современное технологическое оборудование театра, технические возможности сцены и вместимость зрительного зала позволят организовывать гастроли различных ведущих российских и мировых театральных коллективов. Также сцена филиала Мариинского театра станет стартовой площадкой, началом профессиональной карьеры выпускников филиала Московской государственной академии хореографии.
Ещё одной интересной идеей в области развития хореографического искусства станет возможное создание на базе филиала Государственного академического Мариинского театра Балетной Школы Илзе Лиепы. Предполагается, что преподавание в данной школе будет основано на методе Илзе Лиепы, основанном на уникальной системе гармоничного физического и духовного развития человека [9].

Один из символов России - это русский балет. Указом Президента Российской Федерации № 15 от 16 января 2016 года Московская государственная академия хореографии, являющая лучшей балетной школой в мире, была отнесена к особо ценным объектам культурного наследия народов Российской Федерации. И в скором времени в Кузбассе появится филиал данной школы. В филиале этого учебного заведения профессиональное балетное образование смогут получать талантливые дети, в том числе, и из других субъектов Российской Федерации. Предполагается, что именно выпускники кузбасского филиала Московской государственной академии хореографии станут основой сибирской балетной труппы, которая сможет работать на сцене филиала Мариинского театра. Преподавать в новом учебном заведении и готовить артистов балета будут как ведущие педагоги Кузбасса и Сибири, так и педагоги Московской государственной академии хореографии, приглашённые специально для этого в регион в рамках культурного обмена. Пока филиал Московской государственной академии хореографии не начал функционировать в новом здании, приём будущих артистов балета и их обучение производится на базе хореографического факультета Кемеровского государственного института культуры (далее - КемГИК).

Начиная, с 2020 года филиал Московской государственной академии хореографии в городе Кемерово приглашает на обучение детей на две образовательные программы:

1) «Искусство балета» (срок обучения - 4 года) - дополнительная общеобразовательная предпрофессиональная программа (дети в возрасте 7 лет);

2) «Основы хореографического искусства» (срок обучения 1 год) - дополнительная общеобразовательная общеразвивающая программа (дети в возрасте 8-9 лет) [10].

Долгие годы профессиональное хореографическое искусство в регионе основывалось только на базе Кемеровского государственного института культуры, который готовит преподавателей, балетмейстеров, а с недавних пор и 
артистов ансамблей. Планируется, что в филиале Московской государственной академии хореографии дети будут начинать обучение в возрасте в 9-11 лет, что является повсеместной педагогической практикой. Профессиональный стаж артиста балета до выхода на пенсию - 20 лет, именно поэтому открытие в Кузбассе филиала академии позволит обучать детей, начиная с раннего возраста) хореографическому искусству в лучших мировых традициях.

Для получения данных о современном состоянии хореографического искусства в Кузбасce c точки зрения обучающихся факультета хореографии КемГИК автором было проведено практическое исследование. В исследовании приняли участие 54 обучающихся факультета хореографии КемГИК в возрасте от 18 лет до 22 лет по четырём направлениям подготовки: хореографическое искусство (21 человек), руководитель хореографического любительского коллектива (13 человек), артист ансамбля народного танца (10 человек) и артист ансамбля классической и современной хореографии (10 человек).

В рамках исследования использовался метод опроса. Группа опрошенных обучающихся оценила уровень развития хореографического искусства в Кузбассе как:

- «удовлетворительный» (наличие в регионе детских общеобразовательных, среднеспециальных и высших учебных учреждений, осуществляющих подготовку в области хореографического искусства, функционирование учреждений только по нескольким видам хореографического искусства) - 0 человек из 54 $(0 \%)$;

- «хороший» (наличие в регионе детских общеобразовательных, средне-специальных и высших учебных учреждений, осуществляющих подготовку в области хореографического искусства, функционирование учреждений по всем видам хореографического искусства) - 20 из 54 человек (37 \%), среди которых обучающиеся по направлению;

- хореографическое искусство - 7 человек;

- руководитель хореографического любительского коллектива - 5 человек;

- артист ансамбля народного танца -4 человека;

- артист ансамбля современной и классической хореографии - 4 человека;

- «отличныйу» (наличие в регионе детских общеобразовательных, средне-специальных и высших учебных учреждений, осуществляющих подготовку в области хореографического искусства, функционирование учреждений по всем видам хореографического искусства, многоуровневая система подготовки профессиональных кадров в области хореографии) - 34 из 54 человек (63 \%), среди которых обучающиеся по направлению;

- хореографическое искусство - 14 человек;

- руководитель хореографического любительского коллектива - 8 человек;

- артист ансамбля народного танца -6 человек;

- артист ансамбля современной и классической хореографии - 6 человек.

Участниками опроса была дана следующая оценка своей профессиональной подготовки в области хореографии: $(0 \%)$

- «удовлетворительная» - 0 из 54 человек

- «хорошая» - 40 из 54 человек (74\%), среди которых обучающиеся по направлению:

- хореографическое искусство - 15 человек;

- руководитель хореографического любительского коллектива - 10 человек;

- артист ансамбля народного танца -8 человек;

- артист ансамбля современной и классической хореографии - 7 человек.

- «отличная» - 14 из 54 человек (26\%), среди которых обучающиеся по направлению

- хореографическое искусство -7 человек;

- руководитель хореографического любительского коллектива - 3 человека;

- артист ансамбля народного танца - 2 человека;

- артист ансамбля современной и классической хореографии -3 человека.

В группе опрошенных все обучающиеся $(100 \%)$ отмечают, что их уровень профессиональной подготовки с каждым годом растёт, среди них данный рост считают:

- незначительным - 5 человек из 54 (8\%), среди которых обучающиеся по направлению

- хореографическое искусство - 0 человек;

- руководитель хореографического любительского коллектива - 3 человека;

- артист ансамбля народного танца - 1 человек;

- артист ансамбля современной и классической хореографии - 1 человек. 
- значительным - 39 человек из 54 (72 \%), среди которых обучающиеся по направлению

- хореографическое искусство - 21 человек;

- руководитель хореографического любительского коллектива - 10 человек; человек;

- артист ансамбля народного танща - 9

- артист ансамбля современной и классической хореографии - 9 человек.

По результатам ответов опрошенной группы о перспективах развития хореографического искусства в Кузбассе все обучающиеся отмечают значительное улучшение и последующие перспективы его роста. Все опрошенные имеют представление о функциях строящегося в Кузбассе Сибирского кластера искусств. Среди обучающихся была дана следующая оценка уровня его функционирования: $(0 \%)$

- «низкий уровень» - 0 человек из 54

- «средний уровень» - 7 человек из 54

(13\%), среди которых обучающиеся по направлению; век;

- хореографическое искусство - 1 чело-

- руководитель хореографического любительского коллектива - 5 человек; ловек;

- артист ансамбля народного танца - 0 че-

- артист ансамбля современной и классической хореографии - 1 человек;

- «высокий уровень» - 47 человек из 54 $(87 \%)$, среди которых обучающиеся по направлению

- хореографическое искусство - 20 человек;

- руководитель хореографического любительского коллектива - 8 человек;

- артист ансамбля народного танца -10 человек;

- артист ансамбля современной и классической хореографии -9 человек.

Исходя из полученных результатов, можно сделать вывод о том, что уровень развития хореографического искусства в Кузбассе с точки зрения обучающихся факультета хореографии КемГИК с каждым годом растёт и регион становится более привлекательным для специалистов в области профессионального хореографического искусства. Большое влияние на данный рост имеет строящийся в Кузбассе Сибирский кластер искусств, в проекте которого запланировано строительство двух культурных учреждений, имеющих непосредственное отношение к хореографическому искусству: театр оперы и балета (филиал Государственного академического Мариинского театра) и филиал Московской государственной академии хореографии. Данные культурные учреждения будут способствовать развитию в регионе профессионального хореографического искусства и профессиональной подготовке профессиональных артистов балета.

Таким образом, создание Сибирского кластера искусств в Кузбассе станет воплощением задач Государственной культурной политики по развитию русской и национальных культур народов России на региональном уровне как в области профессионального искусства в целом, так и в области профессионального хореографического искусства, в частности.

\section{Список литературы}

1. Указ Президента Российской Федераичи «Об утверждении основ государственной культурной политики» от 24.12.2014 № 808 // Собрание законодательства Российской Федерации. 2014 г. № 52. Ст. 7753.

2. Портер М. Ю. Конкуренция. Москва, $2001.495 \mathrm{c}$.

3. Буреш О. В., Фролов А. В. Кластерный подход в разработке стратегии регионального развития // Экономика и управление. 2012. № 11 (96). С. 60-62.

4. Министерство культуры Российской Федераиии. URL: https://culture.gov.ru/ press/news/ vladimir_medinskiy_predstavil_ sovremennuyu_model_kulturnoy_politiki_v_rossiyskoy_federatsii/ (27.03.2021).

5. Паничкина E. B. Культурные кластеры в региональном измерении // Вестник КемГУКИ. 2019. № 48. С. 103-110.

6. Кулакова Л. И. Кластерный подход - основа эффективного развития регионов // Российское предпринимательство. 2013. № 22 (244). C. 121-130.

7. Андросова Н. О. Условия и предпосылки создания социокультурного кластера в Белгородской области // Научные ведомости БелГУ. 2012. № 2 (121). С. 172-180.

8. Закон Кемеровской области «Об утверждении Стратегии сочиальноэкономического развития Кемеровской области до 2035 года» от 23.12.2020 № 163 - О3 // Законодательное Собрание Кемеровской области Кузбасса. 2020 г.

9. Концепџия Сибирского кластера искусств // Министерство культуры и национальной политики Кузбасса URL: http://mincult- 
kuzbass.ru/kultura-i-iskusstvo/sibirskiy-klasteriskusstv/?PAGEN_2=2 (28.03.2021).

10. Кемеровский государственный инстиmут культуры. URL: https://kemguki.ru/news/v- kemgik-nachala-svoyu-rabotu-priemnaya-komissiya-filiala-moskovskoy-gosudarstvennoyakademii-khoreo/ (27.03.2021).

УДК 908(571.17)+069

DOI: $10.32340 / 2514-772 X-2021-1-34-40$

Е. А. Ермакова

Средняя общеобразовательная школа № 11 (Кемерово, Россия) ermak200712@mail.ru

Н. Я. Сафронова

Народный краеведческий музей-комплекс имени заслуженного учителя РСФСР Петренко П. М. Средняя общеобразовательная школа №11 (Кемерово, Россия) natali.safronova.57@bk.ru

\section{ИСТОРИЯ ВОЕННОГО ЗАВОДА № 319 «КОММУНАР» (ПО МАТЕРИАЛАМ ПОИСКОВО-ИССЛЕДОВАТЕЛЬСКОЙ РАБОТЫ КРАЕВЕДЧЕСКОГО МУЗЕЯ-КОМПЛЕКСА СРЕДНЕЙ ОБЩЕОБРАЗОВАТЕЛЬНОЙ ШКОЛЫ № 11 Г. КЕМЕРОВО)}

Аннотация. С 2020 года в Средней общеобразовательной школе № 11 (г. Кемерово) реализуется проект «Память поколений». Сотрудниками учреждения была проведена поисково-исследовательская работа по восстановлению памяти о заводе «Коммунар»: изучены архивные документы, проведены встречи с ветеранами завода, сбор предметов, касающихся истории завода, собраны воспоминания заводчан и фотоматериалы.

Ключевые слова: история завода, военное время, икольный музей, историко-публицистическое издание.

В свое время И. Эренбург писал: «Для того чтобы патриотизм был крепким и непоколебимым, нужно, чтобы он исходил из любви к своей маленькой родине - родному городу, родной природе, селу, краю». Восстановление и возрождение нашего исторического и духовного наследия, воспитание нравственности, духовности и гражданственности невозможно без уважения к своей истории, культуре, родному краю. Эта проблема крайне актуальна в наши дни и требует к себе особого внимания. Современные дети зачастую знают мало из истории своей малой родины, о Великой Отечественной войне и о людях, которые создавали наше будущее. В связи с этим неуклонно возрастает роль исторического краеведения. Связующей нитью, объединяющей людей разных возрастов, профессий и положения, стала поисковая и исследовательская работа, посвященная изучению истории становления военного завода «Коммунар». Так сложилось, что история школы № 11 тесно связана с летопи- сью этого героического завода, взявшего шефство над школой.

С 2020 года в школе реализуется проект «Память поколений». В рамках реализации этого проекта Советом Народного краеведческого музея-комплекса имени заслуженного учителя Российской Федерации Павла Моисеевича Петренко проведена большая поисковоисследовательская работа по восстановлению памяти о военном заводе «Коммунар»: изучены архивные документы, проведены встречи с ветеранами завода, анкетирование и интервьюирование жителей района, сбор предметов, касающихся истории завода, собраны воспоминания заводчан, фотоматериалы из личных архивов жителей Кировского района. С каждым новым воспоминанием мы погружаемся в прошлое нашей страны, города Кемерово, Кировского района. В семьях хранятся старые фотографии, письма, награды, личные вещи тех, кого с благодарностью вспоминаем мы сегодня. Ветераны завода, жители района поделились 